\title{
Computational analysis of cavitation at the tongue of the volute of a centrifugal pump at overload conditions
}

\author{
Hu, Q. ${ }^{a}$, Yang, Y. ${ }^{a}$, Cao, W. ${ }^{a}{ }^{*}$ \\ ${ }^{a}$ Research Institute of Fluid Engineering Equipment Technology, Jiangsu University, P.R. China
}

\begin{abstract}
A B S T R A C T
Volute pump is the most common used centrifugal pump. As cavitation highly contributes to deteriorating the performance of the pump, anti-cavitation performance is one of its design specifications. To clarify the cavitation evolution at the tongue of the volute of a centrifugal pump at overload conditions and its influence on the flow field in the impeller, numerical simulation with ANSYS CFD and a hydraulic test were conducted on a volute pump at several flow rates above optimal value. The cavity distribution and the blade loading distribution were analyzed. And the characteristics of the pressure fluctuation of the monitoring points located in volute casing were obtained and compared with each other. Results showed that cavitation may first emerge at the tongue rather than the impeller inlet at overload conditions. The alternative stress resulting from periodical radial force increases obviously as the extent of cavitation at the tongue. Meanwhile, the mean cavity length grows as each blade comes close to the tongue, and causes a decrease in performance because of a reduction or closure of flow passages. The pressure pulsation in the volute is consistent with the blade passing frequency whether cavitation occurs or not, while the pulsation intensity increases obviously after cavitation inception. From the first section to the eighth section of volute, the pulsation intensity of impeller outlet decreases gradually. The results are then compared to provide a reference for the optimum design of the anti-cavitation performance of centrifugal pump.
\end{abstract}

\section{ARTICLE INFO}

Keywords:

Centrifugal pump;

Numerical simulation;

Computational fluid dynamics

(CFD);

Tongue;

Cavitation;

Blade loading;

Pressure fluctuation

*Corresponding author:

cwd@ujs.edu.cn

(Cao, W.)

Article history:

Received 18 August 2020

Revised 14 September 2020

Accepted 16 September 2020

(c) 2020 CPE, University of Maribor. All rights reserved.

\section{References}

[1] Brennen, C.E. (2011). Hydrodynamics of Pumps, Cambridge University Press, Cambridge, United Kingdom, doi: 10.1017/CBO9780511976728.

[2] Franc, J.-P., Michel, J.-M.(2005). Fundamentals of cavitation, Springer, New York, USA, doi: 10.1007/1-4020-2233-6.

[3] Širok, B., Dular, M., Hočevar, M., Novak, M., Stoffel, B., Ludwig, G., Bachert, B. (2002). The influence of cavitation structures on the erosion of a symmetrical hydrofoil in a cavitation tunnel, Strojniški Vestnik - Journal of Mechanical Engineering, Vol. 48, No. 7, 368-378.

[4] Wang, S.-L., Tan, L., Wang, Y.-C. (2013). Characteristics of transient cavitation flow and pressure fluctuation for a centrifugal pump, Journal of Vibration and Shock, Vol. 32, No. 22, 168-173, doi: 10.13465/i.cnki.jvs.2013.22.024.

[5] Bilus, I., Predin, A. (2009). Numerical and experimental approach to cavitation surge obstruction in water pump, International Journal of Numerical Methods for Heat \& Fluid Flow, Vol. 19, No. 7, 818-834, doi: 10.1108/096155 30910984091.

[6] Lu, J., Yuan, S., Ren, X., Liu, Y., Si, Q. (2015). Investigation of instabilities of cavitation at low flow rate of centrifugal pump, Transactions of the Chinese Society for Agricultural Machinery, Vol. 46, No. 8, 54-58, doi: 10.6041/j.issn. 1000-1298.2015.08.009.

[7] Čudina, M., Prezelj, J., Černetič, J. (2012). Use of noise and vibration spectra to detection cavitation in kinetic pumps, In: Proceedings of the $8^{\text {th }}$ International Symposium on Cavitation, Singapore, 978-971, doi: 10.3850/978981-07-2826-7 172. 
[8] Lu, Z., He, X., Wang, C. (2018). Influencing factors of self-priming time of multistage self-priming centrifugal pump, DYNA - Ingeniería e Industria, Vol. 93, No. 6, 630-635, doi: 10.6036/8930.

[9] Ključanin, D., Manđuka, A. (2019). The cantilever beams analysis by the means of the first-order shear deformation and the Euler-Bernoulli theory, Tehnički Glasnik, Vol. 13, No. 1, 63-67, doi: 10.31803/tg-2018080221 $\underline{0608}$.

[10] Luo, X., Zhang, Y., Peng, J., Xu, H. (2008). Effect of impeller inlet geometry on centrifugal pump cavitation performance, Journal of Tsinghua University (Science and Technology), Vol. 48, No. 5, 836-839, doi: 10.3321/i.issn:1000$\underline{0054.2008 .05 .019 .}$.

[11] Castorani, V., Landi, D., Mandolini, M., Germani, M. (2019). CFD simulations of filter houses for power plant gas turbine: Evaluation of differences between 2D and 3D models, DYNA - Ingeniería e Industria, Vol. 94, 145-149, doi: $10.6036 / 8901$.

[12] Blecich, P., Senčić, T., Wolf, I., Bonefačić, I. (2018). Numerical investigation of heat and mass transfer inside a wet cooling tower, Tehnički Glasnik, Vol. 12, No. 3, 131-138, doi: 10.31803/tg-20171017145907.

[13] Kunz, R.F., Boger, D.A., Stinebring, D.R., Chyczewski, T.S., Lindau, J.W., Gibeling, H.J., Venkateswaran, S., Govindan, T.R. (2000). A preconditioned Navier-Stokes method for two-phase flows with application to cavitation prediction, Computers \& Fluids, Vol. 29, No. 8, 849-875, doi: 10.1016/s0045-7930(99)00039-0.

[14] Luo, X., Wei, W., Ji, B., Pan, Z., Zhou, W., Xu, H. (2013). Comparison of cavitation prediction for a centrifugal pump with or without volute casing, Journal of Mechanical Science and Technology, Vol. 27, No. 6, 1643-1648, doi: 10.1007/s12206-013-0411-5.

[15] Bachert, R., Stoffel, B., Dular, M. (2010). Unsteady cavitation at the tongue of the volute of a centrifugal pump, Journal of Fluids Engineering, Vol. 132, No. 6, Article No. 061301, doi: 10.1115/1.4001570.

[16] Xue, M., Park, Y. (2012). Large eddy simulations of separated flow at the casing tongue of an afterburner fuel pump, Journal of Tsinghua University (Science and Technology), Vol. 52, No. 11, 1638-1642, doi: 10.16511/j.cnki. qhdxxb.2012.11.023.

[17] Meng, L., He, M., Zhou, L., Yang, J., Wang, Z., Karney, B. (2016). Influence of impeller-tongue interaction on the unsteady cavitation behavior in a centrifugal pump, Engineering Computations, Vol. 33, No. 1, 171-183, doi: 10.1108/EC-09-2014-0179.

[18] Dular, M., Širok, B., Bachert, R., Stoffel, B. (2005). Transient simulation, visualization and PIV-LIF measurements of the cavitation on different hydrofoil configurations, Strojniški Vestnik-Journal of Mechanical Engineering, Vol. 51, No. 1, 13-27.

[19] Limbach, P., Kimoto, M., Deimel, C., Skoda, R. (2014). Numerical 3D simulation of the cavitating flow in a centrifugal pump with low specific speed and evaluation of the suction head, In: Proceedings of the ASME Turbo Expo 2014: Turbine Technical Conference and Exposition. Volume 2D: Turbomachinery, Düsseldorf, Germany, 16-20, doi: 10.1115/GT2014-26089.

[20] Limbach, P., Skoda, R. (2017). Numerical and experimental analysis of cavitating flow in a low specific speed centrifugal pump with different surface roughness, Journal of Fluids Engineering, Vol. 139, No. 10, Article No. 101201, doi: $10.1115 / 1.4036673$.

[21] Micha Premkumar, T., Sathish Babu, R., Vinoth Kumar, M., Hariram, V., Seralathan, S. (2019). Numerical simulation of hydrodynamic cavitation in centrifugal pump, International Journal of Innovative Technology and Exploring Engineering, Vol. 8, No. 11, 2689-2693, doi: 10.35940/ijitee.k2140.0981119.

[22] Al-Obaidi, A.R. (2019). Investigation of effect of pump rotational speed on performance and detection of cavitation within a centrifugal pump using vibration analysis, Heliyon, Vol. 5, No. 6, Article No. E01910, doi: 10.1016/ j.heliyon.2019.e01910.

[23] Tang, X., Zou, M., Wang, F., Li, X., Shi, X. (2017). Comprehensive numerical investigations of unsteady internal flows and cavitation characteristics in double-suction centrifugal pump, Mathematical Problems in Engineering, Vol. 2017, Article ID 5013826, doi: 10.1155/2017/5013826.

[24] Dönmez, A.H., Yumurtacı, Z., Kavurmacioğlu, L. (2018). The effect of inlet blade angle variation on cavitation performance of a centrifugal pump: A parametric study, Journal of Fluids Engineering, Vol. 141, No. 2, Article No. 021101, doi: $10.1115 / 1.4040557$.

[25] Tao, R., Xiao, R., Wang, Z. (2018). Influence of blade leading-edge shape on cavitation in a centrifugal pump impeller, Energies, Vol. 11, No. 10, Article No. 2588, doi: 10.3390/en11102588.

[26] George, A., Muthu, P. (2015). Review on effects of cavitation in the performance of centrifugal pump, International Journal of Advance Engineering and Research Development, Vol. 2, No. 11, 298-303, doi: 10.21090/ijaerd. $\underline{021148 .}$. 
APEM
Advances in Production Engineering \& Management Letnik 15 | Številka 3 | September 2020 | Strani 295-306 https://doi.org/10.14743/apem2020.3.366
ISSN 1854-6250

Spletna stran: apem-journal.org Izvirni znanstveni članek

\title{
Računalniška analiza kavitacije na jezičku ohišja centrifugalne črpalke pri pogojih preobremenitve
}

\author{
Hu, Q. ${ }^{a}$, Yang, Y. ${ }^{a}$, Cao, $W .{ }^{a,}{ }^{*}$

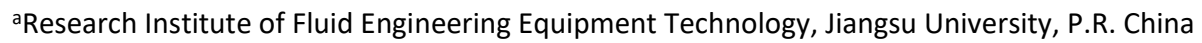

\section{POVZETEK}

Volutna črpalka je najpogosteje uporabljena centrifugalna črpalka. Ker kavitacija v veliki meri prispeva k poslabšanju delovanja črpalke, je protikavitacijska zmogljivost ena izmed njenih konstrukcijskih specifikacij. Da bi razjasnili razvoj kavitacije na jezičku ohišja centrifugalne črpalke pri preobremenitvi in njen vpliv na tokovno polje na impelerju, smo na volutni črpalki izvedli numerično simulacijo z ANSYS CFD in hidravlični preskus pri pretokih nad optimalno vrednostjo. Analizirana je bila porazdelitev votline med jezičkom in lopatico in porazdelitev obremenitve lopatic. Značilnosti nihanja tlaka so bile merjene v nadzornih točkah v ohišju črpalke in med seboj primerjane. Rezultati so pokazali, da se pri preobremenitvi kavitacija najprej pojavi na jezičku ohišja in ne na vstopu v impeler. Obremenitve, ki so posledica periodične radialne sile, se povečajo s povečanjem obsega kavitacije na jezičku. Ko se posamezna lopatica približa jezičku, povprečna dolžina votline narašča, kar povzroči zmanjšanje zmogljivosti črpalke zaradi zmanjšanja ali zapiranja pretočnih poti. Tlačna frekvenca v ohišju je skladna s frekvenco prehajanja lopatic ne glede na to, ali pride do kavitacije ali ne, medtem ko se intenzivnost tlaka po začetku kavitacije poveča. Od prvega do osmega odseka na ohišju se intenziteta tlaka na iztoku iz impelerja postopoma zmanjšuje. Rezultate smo primerjali in predstavili referenco za optimalno oblikovanje protikavitacijskih lastnosti centrifugalne črpalke.

\section{PODATKI O ČLANKU}

Ključne besede:

Centrifugalna črpalka;

Numerična simulacija;

Računska dinamika tekočin (CFD);

Jeziček;

Kavitacija;

Obremenitev lopatic;

Nihanje tlaka

*Kontaktna oseba:

cwd@ujs.edu.cn

(Cao, W.)

Zgodovina članka:

Prejet 18. avgusta 2020

Popravljen 14. septembra 2020

Sprejet 16. septembra 2020 